\title{
Biomass and carbon stocks of the natural forests at Me Linh biodiversity station, Vinh Phuc province, Vietnam
}

\author{
Sinh khối và trũ lượng các bon của thảm thực vật rù̀ng tụ nhiên tại trạm đa \\ dạng sinh học Mê Linh, tỉnh Vĩnh Phúc, Việt Nam \\ Research article
}

Dang, Thi Thu Huong*; Do, Huu Thu

Institute of Ecology and Biological Resources, Vietnam Academy of Science and Technology

\begin{abstract}
Biomass and carbon stock of the natural forests in Vietnam are still not clear due to limitation of knowledge and financial. In this paper, the results of estimating biomass and carbon stocks of the natural forests at Me Linh Biodiversity Station are shown. There are two forest types in this study: the forest vegetation restored after shifting cultivation (vegetation type I) and the forest vegetation restored after clear cutting exploitation (vegetation type II). As the results, the estimated biomass of the forest vegetation restored after shifting cultivation is 86.80 ton.ha ${ }^{-1}$ and the estimated biomass of the forest vegetation restored after clear cutting exploitation is higher, about 131.59 ton.ha ${ }^{-1}$. The carbon stock in plants was about 43.40 ton.ha $^{-1}$ of vegetation type I and 65.79 ton.ha ${ }^{-1}$ of vegetation type II. The carbon storage in soil of vegetation type I is 79.01 ton.ha $^{-1}$ and vegetation type II is 99.65 ton.ha- ${ }^{1}$. Hence, the total of carbon stock in forest vegetation I and II are accounted by 122.41 ton.ha ${ }^{-1}$ and 165.44 ton.h ${ }^{-1}$, respectively. In general, it can be pointed out that the naturally recovering secondary forest at Me Linh Station is the secondary young forest with the low economic value due to shortly restored process (about 10-20 years), the flora is not rich and abundant, and there are only commonly pioneer and light demanding tree species.
\end{abstract}

Sinh khối và trũ luợng các bon của rù̀ng tụ nhiên ở Việt Nam vẫn it được quan tâm của do hạn chế về kiến thức và tài chính. Trong bài báo này, chúng tôi đưa ra kết quả của việc ước lượng sinh khối và tổng hợp các bon của các thảm thực vật rừng thư sinh phục hồi tư nhiên tại Trạ Đa dạng Sinh họ Mê Linh, tỉnh Vĩnh Phúc-Việt Nam, nơi có loại hình thảm thực vật chính, đó là thảm thực vật phuc hồi sau nương rẫy (kiểu thảm thuc vật I) và thảm thực vật phục hồi sau khai thác kiệt (kiểu thảm thưc vật II) nhằm mucc đích đánh giá tiềm năng của rùng thứ sinh tại khu vực nghiên cứu. Sinh khối của thảm thực vật phục hồi sau nương rấy là 86,80 tấn/ha. Sinh khối của thảm thực vật phục hồi sau khai thác cao hơn, đạt 131.59 tẩn/ha. Luợng các bon háp thu trong đất của thảm thưc vật I là 79,01 tấn/ha và thảm thực vật II là 99,65 tấn/ha. Nhu vây, tổng lượng các bon được hấp thu trong mỗi loại hình thảm thực vật trên là: 122,41 tấn/ha (thảm thực vật I) và 165,14 tấn/ha. Nhìn chung, rùng thư sinh phục hồi tụ nhiên tại Trạm Đa dạng Mê Linh chủ yếu là rừng non thư sinh, it có giá trị kinh tế do quá trình phục hồi diến ra ngắn (khoảng 10-20 năm) nên thành phần thực vật nghèo nàn, không phong phú, thành phần chính chủ yếu là các cây gố tiên phong, ua sáng.

Keywords: biomass, carbon stock, natural forest vegetation, restoration, tree biomass, carbon in soil

\section{Introduction}

The main carbon pools in tropical forest ecosystems are keeping in the living biomass of trees and underground vegetation and the dead mass of litter, woody debris and soil organic matter. The carbon stored in the trees is typically the largest part and the most directly impacted by deforestation and degradation $[2,5]$. The biomass is also a valuable indicator to growth rate, condition and yield 
potential of a plant. Thus, estimating biomass is the most important step in quantifying forest $\mathrm{C}$ stocks and monitoring the changes. Studies on biomass and $\mathrm{C}$ stock in tropical forests have been carried out by using several research methods, such as measurement on destructive sampling in experimental plots or based on invention volume of forest (e.g. Brown and Lugo 1989, Brown et al. 1997) $[3,4,8,9,10]$. However, most of the studies focused on the estimation of forest biomass or C-stock at one occasion. Forest biomass and $\mathrm{C}$-stock may be dynamic and changes occur continuously at individual tree and stand levels throughout time due to loss of carbon during deforestation and degradation caused by human activities and accumulation of carbon during re-growth of forests.

Secondary forests are a forest formed by process of natural regeneration on the land of forest lost due to shifting cultivation, forest fire and exploitation. Recently, we have also become aware that secondary rather than primary forests sequester carbon from the atmosphere, a concept that is much discussed in climate conventions around the world. According to the report of Vietnam Administration of Forestry in 2013, area of the secondary forest was accounted about 4,023,040 ha (38.59 percent of total natural forest area). Most of Vietnam's natural forests are affected, the impact in two main directions that are selective cutting (cutting trees used to meet the requirements) [11]. Typically, almost of forest vegetations in Me Linh Biodiversity Station are secondary forest vegetations, which are restored naturally after shifting cultivation and clear cutting exploitation. Data on biomass and $\mathrm{C}$ stock increment for secondary forests are very limited in Vietnam and a gap in Me Linh Biodiversity Station. The objective of this study was to estimate forest biomass and $\mathrm{C}$ stock as well as their increments using inventory data from forest vegetations collected in Me Linh Biodiversity Station.

\section{Materials and methods}

\subsection{Study area}

The study is conducted in secondary forests of Me Linh Biodiversity Station, Vinh Phuc province, Vietnam, which is located in $21^{0} 23^{\prime} 57^{\prime}$ ', $21^{0} 25^{\prime} 35^{\prime}$ 'S latitude and $105^{\circ} 42^{\prime} 40^{\prime}$ ' - $105^{\circ} 46^{\prime} 65^{\prime}$ ' E longitude (Figure 1), distributed between $100 \mathrm{~m}$ and $500 \mathrm{~m}$ above sea level (a.s.l) and total area is about $178 \mathrm{ha}$ and adjacent to Tam Dao National Park [13]. According to report of Vinh Phuc province in 2010, the average precipitation about $1358.7 \mathrm{~mm}$ /annual, temperature $23.9^{\circ} \mathrm{C}$ and is tropical monsoon climate, ferrallit soil classification (FAO classification; FAO, 2006) and high humid. The main soil properties were iron and aluminum, hence the soil is acidity, thin layer and rocky $[6,7]$.

\section{FOREST MAPPING OF ME LINH STATION FOR BIODIVERSITY}
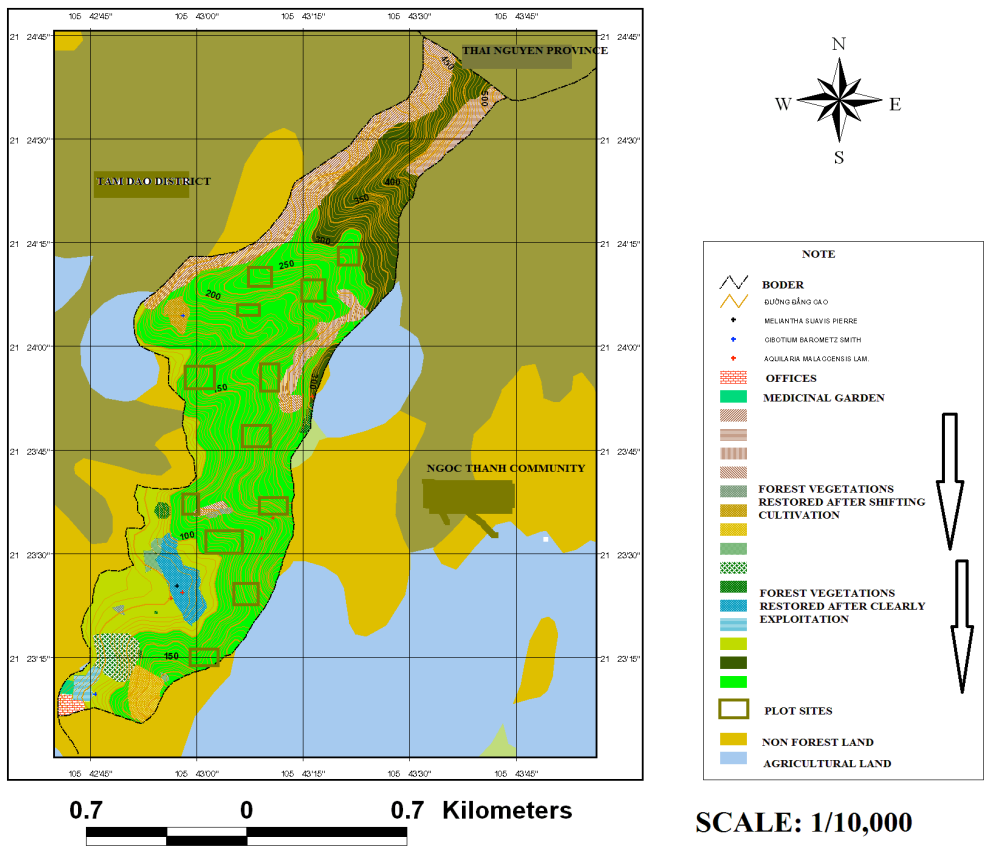

Figure 1. Plots plan in Me Linh Biodiversity Station, Vinh Phuc province

\subsubsection{Forest and flora}

The forests in the study derived from tropical monsoon evergreen closed forest and they were significantly disturbed through exploiting activity of human as logging, clear cutting, grazing and the collection of fuel-wood.
Hence, most of the primary forests in here are changed into two main secondary forest types as the secondary forest restored after shifting cultivation and the secondary forest restored after clearing exploitation (Le Dong Tan, 2003) [12]. The area of the secondary forests restored after clear cutting exploitation is larger than that of the 
other type, about 85.7 ha (48.01\% total area of the Station) and it is often distributed on the altitude $>95 \mathrm{~m}$ a.s.1. The area of the secondary forest restored after shifting cultivation accounted about 38.9 ha $(21.79 \%)$ and distributed on from $55 \mathrm{~m}$ to $79 \mathrm{~m}$ a.s. 1 .

The flora was recorded 166 families, 651 genera and 1129 species belonging to four divisions of high vascular plant, including: Lycopodiophyta, Equisetophyta, Polypodiophyta, Magnoliophyta. The most of plant composition belongs to families: Lauraceae, Fagaceae, Moraceae, Magnoliaceae, Fabaceae, Anacardiaceae, Burseraceae, Sapindaceae, Hamamelidaceae and Bombacaeae (Nguyen Tien Ban, 2000) [1].

\subsubsection{Plot selection}

Selecting plots in homogenous vegetation patches. Each plot size was $50 \mathrm{~m} \times 50 \mathrm{~m}$ ( $0.25 \mathrm{ha}$ plot). The total of ten plots is chosen to survey and gather parameter in two forest types. In each of plot five subplots with the size of $(5 \mathrm{mx} 5 \mathrm{~m})$ have been created to survey and to gather data on shrub, grass and litter.

Collecting and identifying species in plots and carrying measurement all trees with their diameter $>5 \mathrm{~cm}$ (at $1.3 \mathrm{~m}$ ) and $>5 \mathrm{~m}$ in height.

\subsection{Methods of sampling selection}

\subsubsection{Selecting sample tree (represented tree)}

Tree is selected that is dominant species in each community with its diameter value in the medium of each diameter class (diameter parameter is divided into five class as class I: $5-10 \mathrm{~cm}$; class II: $>10-15 \mathrm{~cm}$; class $3:>15-20 \mathrm{~cm}$; class $4: 20-25 \mathrm{~cm}$ and class $5:>25 \mathrm{~cm})$. Twenty tree species represent 58 species are chosen to take sample and the total number of represented trees to estimate biomass accounted 100 individuals.

A tree is cut down close to the ground and divided into three parts: stem, branch and leave as well as weighted to estimate the above ground fresh biomass. Root is a part of the tree to determine below ground fresh biomass. Root is dug and gathered all of diameter's roots greater than 2 $\mathrm{mm}$.

\subsubsection{Selecting sample in shrubs and grass layer}

Biomass of shrubs layer and herbaceous are collected in each a subplot. All shrubs and herbaceous are cut down and weighted its fresh biomass.

\subsubsection{Selecting sample of litter}

In each a subplot is designed a plot with $1 \mathrm{mx} 1 \mathrm{~m}$ size to gather litter sample (all of branch, leave, flower and fruit) and weighted to determine the weight of litter in the field.

\subsubsection{Selecting sample for estimating ovendry biomass}

Four types of dry biomass samples are taken, corresponding to each tree felled criteria: stem, branch, leave and root.

+ Stem: taking 3 different positions as top of stem, bottom of stem and bottom of the fork, cutting each position with a thickness of $3 \mathrm{~cm}$, the sample volume accounted for approximately $0.2 \%$ of the fresh weight.

+ Branch: taking 4 small cutting board stem from the sample volume was $0.5 \mathrm{~kg}$.

+ Leave: mixing leaves and taking 01 sample of $0.5 \mathrm{~kg}$.

+ Root: taking a sample in tap-root and another taken in lateral root with volume of $0.5 \mathrm{~kg} /$ sample.

All samples are cut small and dried in the oven at $70-85^{\circ} \mathrm{C}$ and the heating time depends on the part of plant body, but until gets constant weight.

\subsection{Data analysis}

Estimation of oven-dry biomass of tree/shrub/grass/litter

$$
\mathrm{Mk}_{\mathrm{i}}=M i \times \frac{m k_{i}}{m_{i}} \quad(\mathrm{~kg})
$$

Where:

$\mathrm{Mk}_{\mathrm{i}}$ : oven-dry biomass of each part of individual; $\mathrm{M}_{\mathrm{i}}$ : fresh biomass of each part of individual; $\mathrm{mk}_{\mathrm{i}}$ : mass of dry sample of each part after drying and $\mathrm{m}_{\mathrm{i}}$ : mass of fresh sample of each part of individual

\section{Estimation of dry biomass of represented tree (sampled tree)

$$
\mathrm{P}_{\mathrm{i} \text {-tree }}=\mathrm{P}_{\mathrm{i}-\text { stem }}+\mathrm{P}_{\mathrm{i} \text {-branch }}+\mathrm{P}_{\mathrm{i} \text {-leaf }}+\mathrm{P}_{\mathrm{i} \text { - root }} \quad(\mathrm{kg})
$$

Where: $\mathrm{P}_{\mathrm{i}}$ : dry biomass of each part of sampled tree for a diameter class.

\section{Biomass equations for tree}

Estimating the biomass calculation of Saltonstall Ridge, the method can be applied biomass equations from "Biomass Equations for Sixty-Five North American Tree Species" published in Forest Ecology and Management. The equations for biomass estimation were developed by relating biomass to tree diameter at breast height (DBH) and other tree characteristics.

Allometry equations are usually expressed in one of two forms

- $\quad$ biomass $=\mathrm{a} \mathrm{dbh}^{\mathrm{b}}$

- $\quad$ biomass $=\mathrm{a}+\mathrm{b} \log (\mathrm{dbh})$

These equations give a reasonable estimate of above ground biomass based on tree species and diameter.

\section{Estimation of dry biomass of tree layer in a plot by}

$$
\mathrm{P}_{\text {otc }}=\mathrm{n}_{1} \cdot \mathrm{P}_{1}+\mathrm{n}_{2} \cdot \mathrm{P}_{2}+\mathrm{n}_{3} \cdot \mathrm{P}_{3}+\ldots+\mathrm{n}_{\mathrm{i}} \cdot \mathrm{P}_{\mathrm{i}} \quad \text { (ton.ha }{ }^{-1} \text { ) }
$$

Where: $\mathrm{P}$ : dry biomass of tree layer in a plot; $\mathrm{n}_{1,2,3, ., \mathrm{i}}$ : density of trees of each diameter class; $\mathrm{P}_{1,2,3 ., \mathrm{i}}$ : dry biomass of tree sample in each diameter class.

\section{Estimation of dry biomass of plant}

$$
\left.\mathrm{P}_{\text {plant }}=\mathrm{P}_{\text {tree layer }}+\mathrm{P}_{\text {shrub/grass layer }}+\mathrm{P}_{\text {litter }} \quad \text { (ton.ha }{ }^{-1}\right)
$$

Where: $\mathrm{P}_{\text {plant }}$ : Dry biomass of plant; $\mathrm{P}_{\text {tree layer }}$ : dry biomass of tree layer; $\mathrm{P}_{\text {shrub, grass layer: }}$ dry biomass of shrub and grass layer and $\mathrm{P}_{\text {litter }}$ : dry biomass of litter 
The total carbon for each plot is then determined by multiplying the biomass per hectare by the proportion of biomass that is carbon. Unless a locally derived alternative is available it should be assumed that $50 \%$ of woody biomass is carbon.

\section{Carbon content in soils calculation:}

In each forest type (status), 3 soil samples have been collected at the depth of $0-30 \mathrm{~cm}$ of the soil sample. The analytic parameters are soil humus and density. Total carbon content storage in soils is based on the method of Walkley - Black, the carbon content can be extracted by $\mathrm{K} 2 \mathrm{Cr} 2 \mathrm{O} 7$ and $\mathrm{H} 2 \mathrm{SO} 4$ solutions with Morh neutralization. Hence, total $\mathrm{C}$ can be estimated to $58 \%$ of total soil humus. Express by equation (IPCC, 2003):

$$
\mathrm{C}_{\text {in soil }}=\mathrm{h} \times \mathrm{D} \times \mathrm{C}_{\mathrm{s}} \times \mathrm{UFC}
$$

Where: UFC exchange factor $100 ; \mathrm{C}_{\mathrm{s}}$ : Carbon content storage in soil humus (\%); h: depth of soil sampling (m); D: Soil density $\left(\mathrm{gr} / \mathrm{cm}^{3}\right)$.

\section{Hence, total C can be estimated by:}

$$
\left.\Sigma \mathrm{C}_{\text {in forest vegetation }}=\Sigma\left(\mathrm{C}_{\text {plant }}+\mathrm{C}_{\text {in soil }}\right) \quad \text { (ton.ha } \mathrm{ha}^{-1}\right)
$$

\section{Results and discussion}

\subsection{Characteristics of natural forest vegetations in Me Linh Biodiversity Station}

\subsubsection{Species richness and stand structure}

The secondary forests in Me Linh Biodiversity Station are represented by two main forest vegetation types, including: the forest vegetation restored after shifting cultivation and the forest vegetation restored after clear cutting exploitation. Almost of the area in the study is the forest vegetation restored after clear cutting exploitation, accounted 68.39 percent of total area and another one is 31.61 percent, respectively.

Overall, randomly ten plots were established for each of forest type, which is 5 ha per each and more than 2,800 tree individuals of 58 tree species belonging to 43 genera and 31 families are recorded. They are Lauraceae, Fagaceae, Fabaceae, Burseraceae, Spindaceae, Magnoliaceae and Moraceae. The dominant tree species in forest types, including: Macaranga denticulata (Blume) Muell.-Arg.; Bischofia javanica Blume; Castanopsis indica (Roxb.) A. DC.; Litsea lancilimba Merr.; Machilus parviflora Meisn.; Aglaia spectabilis (Miq.) Jain; Knema globularia (Lamk.) Warrb.; Syzygium formosum (Wall.) Masam; Wendlandia paniculata (Roxb.) DC.; Sapindus saponaria L.; Styrax tonkinensis (Pierre) Craib. ex Hartwiss; Symplocos laurina (Retz) Wall.; Aquilaria crassna Pierre ex Lecomte; Saraca dives Pierre; Canarium album (Lour.) Raeusch.; Rhus chinensis Muell.; Toxicodendron succedanea (L.) Mold.; Liquidamba formosana Hance; ect.

Species compositions of tree layer of above two vegetation types are different. The structure of the forest vegeta- tion restored after shifting cultivation (after 7-15 years) is simple as like a main tree layer and shrub and grass layer, has a typical composition of pioneer and fast grown species such as: Litsea sp.; Liquidamba formosana; Macaranga denticulata; Mallotus apelta (Lour.) Muell.Arg-; Phyllanthus emblica L.; Cratoxylum cochinchinense (Lour.) Blume; Wendlandia paniculata; Euodia lepta (Spreng) Merr.. However, with the forest vegetation restored after clear cutting exploitation due to the restoration time about 15-25 years so that the structure of tree layers is complex, it divides into two stories that are the ecologically dominant story (A2- height of trees from $20 \mathrm{~m}$ to $30 \mathrm{~m}$ ) and the understory (A3- height of trees from $8 \mathrm{~m}$ to $15 \mathrm{~m}$ ) as well as the component of tree species together with the pioneer species also new shade-tolerant tree species in early stage as Saraca dives; Aglaia spectabilis; Syzygium formosum; Pometia pinnata; ; Duabanga grandiflora (Roxb. ex DC.) Walp.

Based on the characteristics of tree species in each forest status in the study areas, it can be pre-concluded that, the carbon stock is mostly dependent on the dominant trees in forest. Therefore, the carbon sequestration will transfer from light demanding plant species to shadow plant species when the time of vegetation restoration has been raised.

\subsubsection{Parameters of density and diameter of stem}

Density and diameter of stem $\left(\mathrm{DBH}_{1.3 \mathrm{~m}}\right)$ are identified by carbon sequestration in parts of tree or forest vegetation. All of vegetation types are restored naturally and still young, hence, the density and the growth of tree individual are uneven. The summarization of estimating density and diameter of stems are shown in the Table 1.

Table 1. The result of estimating density and diameter of stems of two forest types in Me Linh Biodiversity Station

\begin{tabular}{ccc}
\hline \multirow{2}{*}{ Index } & \multicolumn{2}{c}{ Natural forest vegetations } \\
\cline { 2 - 3 } & Vegetation type I & Vegetation type II \\
${\text { Density }\left(N . h a^{-1}\right)}_{\mathrm{DBH}_{1,3 \mathrm{~m}}(\mathrm{~cm})}^{385}$ & 577 \\
\hline
\end{tabular}

It can be seen that the average of stem diameter of the vegetation $I$ is accounted about $13.8 \mathrm{~cm}$ and smaller than that of the vegetation II $(17.8 \mathrm{~cm})$. Similarly, the average of stem density of the vegetation II is valued in 577 individual.ha ${ }^{-1}$ and more than that of the other type (385 individual.ha ${ }^{-1}$ )

\subsection{Biomass of tree sample}

Twenty dominant tree species are collected and cut down to account biomass of a tree of a species in each diameter class. Summarize data on these biomass allowed to estimate average of each species and the results are shown in the Table 2 .

The data on Table 2 indicated that each tree species is valued different biomass like the biomass of Bischofia javanica achieved $75.15 \mathrm{~kg}$.tre ${ }^{-1}$; Macaranga denticulata 
(Blume) Muell.-Arg.: 33.20kg.tree ${ }^{-1}$; Liquidambar for- $\quad$ mosana Hance: 65.40 kg.tree ${ }^{-1}$; ect.

Table 2. Biomass of tree samples in two forests in Me Linh Biodiversity Station

\begin{tabular}{|c|c|c|c|c|c|c|c|c|c|}
\hline No. & Scientific name & AGB & BGB & $\begin{array}{c}\Sigma \text { biomass } \\
\text { of a tree } \\
\text { sample }\end{array}$ & No. & Scientific name & AGB & BGB & $\begin{array}{c}\Sigma \text { biomass } \\
\text { of a tree } \\
\text { sample }\end{array}$ \\
\hline \multirow{3}{*}{$\begin{array}{l}2 \\
3\end{array}$} & $\begin{array}{l}\text { Hydnocarpus kurzii } \\
\text { (King) Warb. }\end{array}$ & 65.53 & 20.55 & 86.08 & 11 & $\begin{array}{l}\text { Wendlandia } \\
\text { paniculata } \\
\text { (Roxb.) DC. }\end{array}$ & 23.22 & 6.90 & 30.12 \\
\hline & Saraca dives Pierre & 30.70 & 6.85 & 37.55 & 12 & $\begin{array}{l}\text { Styrax tonkinen- } \\
\text { sis (Pierre) } \\
\text { Craib. ex Hart- } \\
\text { wiss }\end{array}$ & 40.56 & 13.81 & 54.37 \\
\hline & $\begin{array}{l}\text { Machilus parviflora } \\
\text { Meisn. }\end{array}$ & 40.60 & 7.28 & 47.88 & 13 & $\begin{array}{l}\text { Liquidambar } \\
\text { formosana } \\
\text { Hance }\end{array}$ & 52.62 & 12.78 & 65.40 \\
\hline 4 & $\begin{array}{l}\text { Diospyros eriantha } \\
\text { Champ. ex Benth }\end{array}$ & 55.65 & 13.68 & 69.34 & 14 & $\begin{array}{l}\text { Garcinia oblon- } \\
\text { gifolia Champ. } \\
\text { ex Benth. }\end{array}$ & 67.13 & 13.31 & 80.44 \\
\hline 5 & $\begin{array}{l}\text { Syzygium cinereum } \\
\text { Wall. ex Merr. }\end{array}$ & 68.55 & 18.61 & 87.16 & 15 & $\begin{array}{l}\text { Trema oriental- } \\
\text { is (L.) Blume }\end{array}$ & 38.16 & 6.42 & 44.58 \\
\hline 6 & $\begin{array}{l}\text { Aglaia spectabilis } \\
\text { (Miq.) Jain }\end{array}$ & 68.19 & 21.48 & 89.68 & 16 & $\begin{array}{l}\text { Duabanga } \\
\text { grandiflora } \\
\text { (Roxb. ex DC.) } \\
\text { Walp. }\end{array}$ & 59.17 & 10.82 & 69.99 \\
\hline 7 & $\begin{array}{l}\text { Engelhardtia rox- } \\
\text { burghiana Wall. }\end{array}$ & 37.57 & 14.48 & 52.05 & 17 & $\begin{array}{l}\text { Castanopsis } \\
\text { indica (Roxb.) } \\
\text { A. DC. }\end{array}$ & 64.61 & 33.52 & 98.13 \\
\hline 8 & $\begin{array}{l}\text { Bischofia javanica } \\
\text { Blume }\end{array}$ & 61.95 & 13.20 & 75.15 & 18 & $\begin{array}{l}\text { Aquilaria } \\
\text { crassna } \text { Pierre } \\
\text { ex Lecomte }\end{array}$ & 92.58 & 32.67 & 125.25 \\
\hline 9 & $\begin{array}{l}\text { Knema globularia } \\
\text { (Lamk.) Warrb. }\end{array}$ & 55.82 & 10.54 & 66.36 & 19 & $\begin{array}{l}\text { Canarium } \\
\text { tonkinense } \\
\text { Engl. } \\
\text { Macaranga }\end{array}$ & 41.86 & 8.97 & 50.83 \\
\hline 10 & $\begin{array}{l}\text { Litsea cubeba (Lour.) } \\
\text { Pers. }\end{array}$ & 92.02 & 19.43 & 111.4 & 20 & $\begin{array}{l}\text { denticulata } \\
\text { (Blume) Muell.- } \\
\text { Arg. }\end{array}$ & 26.11 & 7.09 & 33.20 \\
\hline
\end{tabular}

Note: Unit: kg.sample ${ }^{-1}$; AGB: above ground biomass and BGB: Below ground biomass.

In any of these tree species, the biomass is identified mainly concentrated in above ground biomass, approximately 60-75 percent of total biomass. For example: biomass of Engelhardtia roxburghiana Wall. were divided into AGB: $37.57 \mathrm{~kg}$.tre $\mathrm{t}^{-1} \quad(72.18 \%)$ and BGB: $14.48 \mathrm{~kg} \cdot$ tree $^{-1}(27.82 \%)$; biomass of Castanopsis indica (Roxb.) A. DC. accounted AGB: $64.61 \mathrm{~kg} \cdot \operatorname{tree}^{-1}(65.84 \%)$ and BGB: $33.52 \mathrm{~kg} \cdot \operatorname{tree}^{-1}(34.16 \%)$.

\section{Biomass equations for tree}

Biomass equations for individual trees are used to predict the forest production and its relation to stand density, to compare biomass and production for individual tree species, and to estimate forest fuel potential. From the data in the Table 2, biomass equations of each species were developed to estimate above ground biomass of vegetation (Table 3).

Table 3. Biomass equations for tree species in Me Linh Biodiversity Station

\begin{tabular}{|c|c|c|c|c|c|}
\hline No. & Scientific name & $\begin{array}{l}\text { Biomass equa- } \\
\text { tions } \\
\end{array}$ & No. & Scientific name & $\begin{array}{l}\text { Biomass equa- } \\
\text { tions }\end{array}$ \\
\hline 1 & $\begin{array}{l}\text { Hydnocarpus kurzii (King) } \\
\text { Warb. }\end{array}$ & $\mathrm{P}=0.665 \mathrm{D}^{2.781}$ & 11 & $\begin{array}{l}\text { Wendlandia paniculata } \\
\text { (Roxb.) DC. }\end{array}$ & $\mathrm{P}=0.629 \mathrm{D}^{2.660}$ \\
\hline 2 & Saraca dives Pierre & $\mathrm{P}=0.915 \mathrm{D}^{1.104}$ & 12 & $\begin{array}{l}\text { Styrax tonkinensis (Pierre) } \\
\text { Craib. ex Hartwiss }\end{array}$ & $\mathrm{P}=0.590 \mathrm{D}^{1.589}$ \\
\hline 3 & $\begin{array}{l}\text { Machilus } \\
\text { Meisn. }\end{array}$ & $\mathrm{P}=1.05 \mathrm{D}^{2.668}$ & 13 & $\begin{array}{l}\text { Liquidambar formosana } \\
\text { Hance }\end{array}$ & $\mathrm{P}=0.955 \mathrm{D}^{2.058}$ \\
\hline 4 & $\begin{array}{l}\text { Diospyros eriantha } \\
\text { Champ. ex Benth }\end{array}$ & $\mathrm{P}=1.556 \mathrm{D}^{0.998}$ & 14 & $\begin{array}{l}\text { Garcinia oblongifolia } \\
\text { Champ. ex Benth. }\end{array}$ & $\mathrm{P}=0.771 \mathrm{D}^{1.614}$ \\
\hline
\end{tabular}




\begin{tabular}{|c|c|c|c|c|c|}
\hline No. & Scientific name & $\begin{array}{l}\text { Biomass equa- } \\
\text { tions }\end{array}$ & No. & Scientific name & $\begin{array}{c}\text { Biomass equa- } \\
\text { tions }\end{array}$ \\
\hline 5 & $\begin{array}{l}\text { Syzygium cinereum Wall. } \\
\text { ex Merr. }\end{array}$ & $\mathrm{P}=0.794 \mathrm{D}^{2.450}$ & 15 & $\begin{array}{l}\text { Trema orientalis } \quad \text { (L.) } \\
\text { Blume }\end{array}$ & $\mathrm{P}=1.550 \mathrm{D}^{2.290}$ \\
\hline 6 & $\begin{array}{l}\text { Aglaia spectabilis (Miq.) } \\
\text { Jain }\end{array}$ & $\mathrm{P}=0.629 \mathrm{D}^{1.776}$ & 16 & $\begin{array}{l}\text { Duabanga grandiflora } \\
\text { (Roxb. ex DC.) Walp. }\end{array}$ & $\mathrm{P}=1.403 \mathrm{D}^{2.037}$ \\
\hline 7 & $\begin{array}{l}\text { Engelhardtia roxburghia- } \\
\text { na Wall. }\end{array}$ & $\mathrm{P}=0.845 \mathrm{D}^{1.007}$ & 17 & $\begin{array}{l}\text { Castanopsis } \\
\text { (Roxb.) A. DC. }\end{array}$ & $\mathrm{P}=1.05 \mathrm{D}^{2.668}$ \\
\hline 8 & Bischofia javanica Blume & $\mathrm{P}=1.239 \mathrm{D}^{2.001}$ & 18 & $\begin{array}{l}\text { Aquilaria crassna Pierre } \\
\text { ex Lecomte }\end{array}$ & $\begin{array}{l}\mathrm{P}=2.103 \\
1.396 \operatorname{lnD}\end{array}$ \\
\hline 9 & $\begin{array}{l}\text { Knema globularia (Lamk.) } \\
\text { Warrb. }\end{array}$ & $\mathrm{P}=0.905 \mathrm{D}^{1.115}$ & 19 & $\begin{array}{l}\text { Canarium tonkinense } \\
\text { Engl. }\end{array}$ & $\begin{array}{l}\mathrm{P}=1.998 \\
0.578 \ln \mathrm{D}\end{array}$ \\
\hline 10 & Litsea cubeba (Lour.) Pers. & $\mathrm{P}=0.790 \mathrm{D}^{2.643}$ & 20 & $\begin{array}{l}\text { Macaranga denticulata } \\
\text { (Blume) Muell.-Arg. }\end{array}$ & $\begin{array}{l}\mathrm{P}=3.008 \\
0.771 \ln \mathrm{D}\end{array}$ \\
\hline
\end{tabular}

Note: $\mathbf{P}=$ ovendry weight of biomass component of tree in kilograms; $\mathbf{D}=\mathrm{dbh}$ in centimeters; $\mathbf{a}$ and $\mathbf{b}$ are parameters and are different for every species.

\subsection{Carbon stock of the forest vegetations in Me Linh Biodiversity Station}

\subsubsection{Biomass and carbon stock of plants}

The results of biomass and carbon stock are shown in table 4 . In each vegetation type, biomass of tree layer has the highest value in three biomass indexes, in comparison with the biomass of shrub and grass and the biomass of litter. For example, vegetation type I: biomass of tree layer is 66.04 ton.ha $^{-1}$ and approximately $76.08 \%$ of total of vegetation biomass; biomass of shrub and grass is
15.90 ton.ha $^{-1}(18.31 \%)$ and biomass of litter is 4.86 ton.ha ${ }^{-1}(5.59 \%)$.

In addition, biomass of stem, branch and leaf is often higher than biomass of roots and the biomass of shrub is always higher than biomass of grass. Typically in example of vegetation type II, biomass of stem, branch and leaf is achieved 69.70 ton.ha ${ }^{-1}$ and approximately $71 \%$ of total of biomass of tree layer; biomass of shrub is valued 18.55ton.ha ${ }^{-1}$ and about $70.45 \%$ of total of shrub and grass biomass.

Table 4. Dry biomass and carbon stock of plant in Me Linh Biodiversity Station

\begin{tabular}{|c|c|c|c|c|c|c|c|c|c|}
\hline \multirow{2}{*}{ Vegetation type } & \multicolumn{3}{|c|}{ Biomass of tree layer } & \multicolumn{3}{|c|}{ Biomass of shrub and grass } & \multirow{2}{*}{$\begin{array}{c}\text { Biomass of } \\
\text { litter }\end{array}$} & \multirow{2}{*}{$\begin{array}{l}\text { Sum of } \\
\text { biomass }\end{array}$} & \multirow{2}{*}{$\begin{array}{l}\text { Sum of } \\
\text { Carbon }\end{array}$} \\
\hline & $\mathrm{ABG}$ & BBG & $\Sigma$ & ABG & BBG & $\Sigma$ & & & \\
\hline Vegetation type I & 49.35 & 16.69 & 66.04 & 12.86 & 3.04 & 15.90 & 4.86 & 86.80 & 43.40 \\
\hline Vegetation type II & 69.70 & 28.47 & 98.17 & 18.55 & 7.78 & 26.33 & 7.09 & 131.59 & 65.79 \\
\hline
\end{tabular}

Note: unit: ton. a $^{-1}$

Finally, biomass of vegetation is accounted by the sum of three biomass types, including: biomass of tree layer, biomass of shrub and grass and biomass of litter. The biomass of vegetation type I is valued 86.80 ton.ha $^{-1}$ and lower than biomass of vegetation type II (131.59 ton.ha $\left.{ }^{-1}\right)$. Therefore, carbon sequestration of vegetation $\mathrm{I}$ is accounted on 43.4 ton.ha ${ }^{-1}$ and lower than carbon sequestration of vegetation type II ( 65.79 ton.ha $\left.^{-1}\right)$. It can be concluded that biomass and carbon stock of forest vegetation depend strongly on the time of growth and tree species as well as density of individuals of vegetation because the longer forest restoration was, the more plant species develope, plant density is higher and the carbon content in plant is higher than another one.

\section{Carbon stock in soil}

In realistic condition, the naturally restored secondary forest is affected differently by human activities. Therefore, examination of carbon sequestration in soils is only to supply information for existing land use evaluation and there is no further comparison process conducted.

The result in table 5 has shown that the carbon content in soil of vegetation type I and type II were 79.01 ton.ha ${ }^{-1}$ and 99.65 ton. ha $^{-1}$, respectively.

Table 5. Carbon stock in soil of natural forest vegetations in Me Linh Biodiversity Station

\begin{tabular}{lcccc}
\hline Vegetation type & $\begin{array}{c}\text { Depth from ground } \\
(\mathrm{m})\end{array}$ & $\mathrm{D}\left(\mathrm{g} / \mathrm{cm}^{3}\right)$ & $\mathrm{C}$ (percent- \%) & $\begin{array}{c}\text { Carbon content } \\
\left(\text { ton.ha }^{-1}\right)\end{array}$ \\
\hline Vegetation type I & 0.3 & 1.009 & 2.257 & 79.01 \\
Vegetation type II & 0.3 & 1.360 & 2.702 & 99.65 \\
\hline
\end{tabular}




\section{Carbon stock of forest vegetation}

Based on the results from table 4 and table 5, it can be calculated the Carbon content in forest areas. The table 4 shows carbon content in vegetation type II is the highest (165.14ton.ha ${ }^{-1}$ ), and higher than vegetation type I (122.41 ton.ha $\left.{ }^{-1}\right)$. Also, the carbon stock in forest vegetation is stored mainly in soil from $60.34 \%$ to $64.55 \%$ of total of carbon and the rest is contributed from plants $(35.45 \%-39.66 \%)$.

Table 6. Carbon stock of forest vegetation in Me Linh Biodiversity Station

\begin{tabular}{|c|c|c|c|c|c|}
\hline \multirow[t]{2}{*}{ Vegetation type } & \multicolumn{2}{|c|}{ Carbon content of plants } & \multicolumn{2}{|c|}{ Carbon content of soil } & \multirow{2}{*}{$\begin{array}{l}\Sigma \text { carbon } \\
\text { stock }\end{array}$} \\
\hline & $\mathrm{C}\left(\right.$ ton ha $\left.^{-1}\right)$ & Percent $(\%)$ & $\mathrm{C}\left(\right.$ ton $\left.\cdot \mathrm{ha}^{-1}\right)$ & Percent (\%) & \\
\hline Vegetation type I & 43.40 & 35.45 & 79.01 & 64.55 & 122.41 \\
\hline Vegetation type II & 65.49 & 39.66 & 99.65 & 60.34 & 165.14 \\
\hline
\end{tabular}

\section{Conclusion}

The status of natural forest vegetations in Me Linh Biodiversity Station is of two types as the forest vegetation restored after shifting cultivation and the forest vegetation restored after clear cutting exploitation. The plants in the vegetations are commonly of the pioneer and light demanding tree species. However, in the vegetation restored after clear cutting exploitation is the complex species component due to appearance of trees that like shadow at the first developing forest. The average tree diameter of vegetation type I and vegetation type II achieved $13.8 \mathrm{~cm}$ and $17.8 \mathrm{~cm}$, respectively.

The above ground biomass of the parts of each tree sample is accounted main concentration on stem, next to branch and then leaf. The biomass of each plant is different value, including the vegetation type I valued 86.90 ton.ha ${ }^{-1}$ and the vegetation type II valued 131.59 ton.ha ${ }^{-1}$. Of which, the biomass of tree layer is always higher than biomass of shrub and grass layer and biomass of litter as well as biomass of below ground (root), approximately 70.8 percent of total biomass of plant).

The carbon stock in plant is estimated about 43.40 ton.ha ${ }^{1}$ of vegetation type I and 65.79 ton.ha $^{-1}$ of vegetation type II. The carbon storage in soil of vegetation type I is 79.01 ton.ha ${ }^{-1}$ and vegetation type II is 99.65 ton.ha- ${ }^{1}$. Thus, the total of carbon stock in forest vegetation type I and type II is 122.41 ton. ha $^{-1}$ and 165.14 ton.ha ${ }^{-1}$, respectively.

\section{Acknowledgements}

This study was supported by the Science Foundation of Vietnam Academy of Science and Technology for the project "Estimation of biomass and carbon store of natural forest vegetations in evergreen forest ecosystem on land mountain in Me Linh Biodiversity Station, Vinh Phuc province, Vietnam”, period 2013-2014.

\section{References}

[1] Nguyen, T.B. 2000. The report of list of plant in $\mathrm{Me}$ Linh Biodiversity Station.

[2] Bao, H., Pham, T.A., Vo, H., Nguyen, T.T.H. 2012. Report on estimation of $\mathrm{CO}_{2}$ sequestered in evergreen broad leaf forest in Central Highland of Vi- etnam for reducing deforestation and forest degradation program. Tay Nguyen University, Dak Lac.

[3] Brown, S., Gillespie, A.J.R., Lugo, A.E. 1989. Biomass estimation methods for tropical forest with application to forest inventory data. Forest Science 35: 881-902

[4] Brown, S. 1997. Estimating Biomass and Biomass Change of Tropical Forests: a Primer. (FAO Forestry Paper - 134). FAO Forestry Paper 134, FAO, Rome.

[5] Chave, J., Andalo, C., Brown, S., Cairns, M.A., Chambers, J.Q., Eamus, D., Folster, H., Fromard, F., Higuchi, N., Kira, T., Lescure, J.P., Nelson, B.W., Ogawa, H., Puig, H., Rie'ra, B., Yamakura, T. (2005). Tree allometry and improved estimation of carbon stocks and balance in tropical forests. Oecologia 145: 87-99

[6] FAO 2006. Guidelines for Country Reporting to the Forest Resource Assessment 2010. Food \& Agriculture Organisation of the United Nations (FAO), Rome.

[7] FAO 2010. Global forest resource assessment 2010. FAO forestry paper 163 . Food \& Agriculture Organisation of the United Nations (FAO), Rome.

[8] IPCC 2003. Good practice guidance for land use, land use change and forestry. Intergovernmental Panel on Climate Change (IPCC), Geneva.

[9] IPCC 2006. IPCC Guidelines for National Green House Gases Inventory. Volume 4 "Agriculture, Forestry and Other Land Use". Intergovernmental Panel on Climate Change (IPCC), Geneva.

[10] Le, D.T. 2003. The status of forests in Me Linh Biodiversity Station

[11] Raae, K., Christensen, P.C., Vu, T.P., Vu, T.D. 2010. Technical Report onTechnical Assistance in the Development of the National REDD Programme of Vietnam: Componentof Collecting Information and Analyzing Trends of Forest Resources and Forest Carbon

[12] Stock for Establishment of the Interim Baseline Reference Scenarios. Vietnam Administrationof Forestry, Hanoi, 2013

[13] The report of status of natural resources in Vinh Phuc province, 2009 